\title{
Greenhouse Gas Emissions of Beef Cow-Calf Grazing Systems in Uruguay
}

\author{
Gonzalo Becoña ${ }^{1}$, Laura Astigarraga ${ }^{2}$ \& Valentin D. Picasso ${ }^{2}$ \\ ${ }^{1}$ Instituto Plan Agropecuario, Uruguay \\ ${ }^{2}$ Facultad de Agronomía, Universidad de la República, Uruguay \\ Correspondence: Valentin D. Picasso, Facultad de Agronomía, Universidad de la República, Avda. E. Garzón \\ 780, Montevideo, Uruguay. Tel: 598-2354-3460. E-mail: vpicasso@gmail.com
}

Received: February 24, 2014 Accepted: April 7, $2014 \quad$ Online Published: April 21, 2014

doi:10.5539/sar.v3n2p89

URL: http://dx.doi.org/10.5539/sar.v3n2p89

\begin{abstract}
Evaluating greenhouse gas (GHG) emissions at farm level is an important tool to mitigate climate change. Livestock account for $80 \%$ of the total GHG emissions in Uruguay, and beef cow-calf systems are possibly the largest contributors. In cow-calf grazing systems, optimizing forage allowance and grazing intensity may increase pasture productivity, reproductive performance, beef productivity, and possibly reduce GHG emissions. This study estimated GHG emissions per $\mathrm{kg}$ of live weight gain (LWG) and per hectare from 20 cow-calf systems in Uruguay, with different management practices. The GHG emissions were on average $20.8 \mathrm{~kg}$ $\mathrm{CO}_{2}$-e.kg $\mathrm{LWG}^{-1}$, ranging from 11.4 to 32.2 . Beef productivity and reproductive efficiency were the main determinants of GHG emissions. Five farm clusters were identified with different productive and environmental efficiency by numerical classification of relevant variables. Improving grazing efficiency by optimizing the stocking rate and forage production can increase beef productivity by $22 \%$ and reduce GHG emissions per $\mathrm{kg}$ LWG by $28 \%$ compared to "low performance" management. Further improvements in reproductive efficiency can increase productivity by $41 \%$ and reduce GHG emissions per kg LWG by $23 \%$, resulting in a "carbon smart" strategy. However, the most intensified farms with highest stocking rate and beef productivity, did not reduce GHG emissions per kg LWG, while increased GHG emissions per ha compared to the carbon smart. This analysis showed that it is possible to simultaneously reduce carbon footprint per $\mathrm{kg}$ and per ha, by optimizing grazing management. This study demonstrated that there is high potential to reduce cow-calf GHG emissions through improved grazing management.
\end{abstract}

Keywords: carbon footprint, methane, grazing management, nitrous oxide

\section{Introduction}

International concerns about climate change and greenhouse gas (GHG) emissions have grown in the last decades (Intergovernmental Panel on Climate Change [IPCC], 2013). The livestock sector accounts for 14.5\% of the global GHG emissions, and close to half of this is due to the beef sector which accounts for $6 \%$ of the global GHG emissions (Gerber et al., 2013). There is a high potential for reducing GHG emissions, and thereby the carbon footprint, in beef systems worldwide. Carbon footprint is the sum of greenhouse gas emissions throughout the life cycle of a product or a system. It is usually expressed from the standpoint of the consumer, as $\mathrm{kg}$ of $\mathrm{CO}_{2}$ equivalent per unit of a product (De Vries \& de Boer, 2010). It can also be expressed from the standpoint of the producer, as $\mathrm{kg}$ of $\mathrm{CO}_{2}$ equivalent per unit of area of the production system (Reisinger \& Ledgard, 2013). Adequate estimation and analyses of carbon footprint are crucial for identifying opportunities to reduce GHG emissions, especially in countries with large livestock production such as Uruguay, Brazil, New Zealand, or Canada (Modernel, Astigarraga, \& Picasso, 2013; Ruviaro, de Léis, Lampert, Barcellos, \& Dewes, 2014; Beauchemin, Janzen, Little, McAllister, \& McGinn, 2010).

In beef production systems, the cow-calf phase may account for $63 \%$ to $80 \%$ of the total carbon footprint (Pelletier, Pirog, \& Rasmussen, 2010; Beachmin et al., 2010). Several studies highlight the importance of feed quantity and quality to reduce livestock GHG emissions (Pelletier et al., 2010; Beauchmin et al., 2010; Ogino, Orito, Shimada, \& Hirooka, 2007). Furthermore, in cow-calf systems reproductive improvements that enhance productivity of the herd (such as increasing calving rate) may have a major mitigation impact (Beauchemin, Janzen, Little, McAllister, \& McGinn, 2011). 
Livestock grazing management involves managing animal stocking rate, forage allowance, grazing intensity, and type of grazing system. Several studies highlight the central role of grazing management in maximizing forage, animal, and economic productivity at the farm level (Bransby \& Maclaurin, 2000; Sollenberger, Moore, Allen, \& Pedreira, 2005; Stuedemann \& Franzluebbers, 2007). Recent experimental evidence in Uruguay, confirmed that optimizing forage allowance and grazing intensity increased pasture productivity, reproductive performance and beef productivity in cow-calf systems (Carriquiry et al., 2012). A research challenge that still remains is how to analyze and integrate information from variables managed at the field or patch level (e.g., forage allowance), technological variables managed at the farm level (e.g., \% of area in improved pastures) and farm performance variables (e.g., beef productivity or carbon footprint). This paper aims to address this challenge.

Most of the carbon footprint studies are based on model systems defined from average production parameters (Beauchmin et al., 2010) or typical systems identified by consultation with specialists (Modernel et al., 2013; Ruviaro, et al., 2014; Pelletier et al., 2010; Veysset, Lherm, \& Bébin, 2010; Stewart, Little, Ominski, Wittenberg, \& Janzen, 2009). However, estimations from actual livestock systems, taking into account the complex interactions between forage management and reproductive performance that occur in real farms are scarce in the literature (e.g. for lamb and beef: Edwards-Jones, Plassmann, \& Harris, 2009, Ogino et al., 2007; Casey \& Holden, 2006; for dairy: Lizarralde, Picasso, Cadenazzi, Rotz, \& Astigarraga, 2014). Therefore, to assess practical mitigation options at the farm level, studies of carbon footprint on real farms are needed.

Our hypothesis was that cow-calf systems with optimized grazing management could improve animal performance and reduce the carbon footprint. Therefore, the objectives of our study were: (i) to quantify the greenhouse gases emissions for a set of real cow-calf grazing farms in Uruguay, (ii) to identify technological variables more closely associated with carbon footprint in these systems, and (iii) to identify a typology of technological strategies that could lead to reductions in carbon footprint per $\mathrm{kg}$ and per ha.

\section{Method}

\subsection{System Boundaries and Functional Units}

The on-farm GHG sources considered in this study were: $\mathrm{CH}_{4}$ emissions from cattle enteric fermentation and excreta, $\mathrm{N}_{2} \mathrm{O}$ direct emissions from manure and urine in soils, $\mathrm{N}_{2} \mathrm{O}$ indirect emissions from $\mathrm{N}$ leaching, run-off and volatilization, and $\mathrm{CO}_{2}$ emissions from energy used in sowing, fertilization, and other agriculture activities. There is no animal housing involved, and only relevant infrastructure is wire fencing, so it was assumed that $\mathrm{CO}_{2}$ emissions from infrastructure were negligible following IPCC (2006) recommendations. The off-farm GHG sources considered were energy used for herbicide manufacturing and transporting, seed production, and nitrogen and phosphorus fertilizer manufacturing and transporting. Manure in pasture is allowed to lie as is (it is not managed according to IPCC definitions, IPCC, 2006), therefore no direct $\mathrm{N}_{2} \mathrm{O}$ emissions were accounted for it (only indirect emissions from the soil, see below).

Greenhouse gas emissions were expressed in $\mathrm{CO}_{2}$ equivalent units to account for global warming potential of each gas in accordance with IPCC (2006) assuming a 100-year time horizon ( 25 for $\mathrm{CH}_{4}, 298$ for $\mathrm{N}_{2} \mathrm{O}$ and 1 for $\mathrm{CO}_{2}$ ). The functional unit was $\mathrm{kg}$ of live weight gain produced on farm. Cow-calf systems were assumed to be stabilized in terms of animal stock (i.e., the average stock value between beginning and end of year was used for the calculations). Cull cows were included in the analysis. In order to avoid variability in results due to climate or economic conditions that would confound technological variability among farms, data from one fiscal year was used (2010-11) which can be considered a typical climatic year, with annual rainfall similar to the long-term average $(1200 \mathrm{~mm})$.

\subsection{Data Collection and Description of Case Study Farms}

In Uruguayan beef cow-calf systems, animals graze year-round mostly on natural grasslands and pastures. Natural grasslands belong to the Campos ecosystem (grasslands of Uruguay and southern Brazil), similar to the Pampas grasslands in Argentina (Royo Pallares, Berretta, \& Maraschin, 2005). Under traditional continuous grazing (and usually less than $5 \%$ of forage allowance) grasslands quantity and quality limits livestock production. Therefore, other forage sources are introduced by farmers: "improved pastures" (natural grasslands oversown with legumes and fertilized with Phosphorous) and "seeded pastures" (where the original vegetation is replaced with $\mathrm{C} 3$ grasses like Fescue and legumes like Lotus and Clovers, and fertilized with a mix of $\mathrm{N}$ and $\mathrm{P}$, tipially lasting 3 to 4 years). The cattle is predominantly Hereford, Aberdeen Angus, and cross breeds of these two. Heifers first mating (i.e., first serving) is at around 2.5 years of age. Cows calve mostly in early spring (September-October), and calves are weaned in the fall, at around 6 months of age, and 130 to $150 \mathrm{~kg}$ of live weight. No animal housing is needed, cattle is grazing open air year round. Usually less than $1 \%$ of intake of concentrates or hay are fed to cattle. The national average weaning rate for 2011 was $68 \%$ (Ministerio de 
Ganadería, Agricultura y Pesca [MGAP, Ministry of Livestock, Agriculture, and Fisheries], 2012).

In this study, data was collected from 20 actual beef farms located northern and eastern Uruguay. Farms were not randomly selected so they were not necessarily a representative sample of the country (our aim was to identify enough diversity of farms, rather than estimating a country average). The beef farms analyzed were studied by the Instituto Plan Agropecuario (IPA, Agriculture Planning Institute), a Uruguayan institution of agriculture extension. The farms selected for the study had a history of good record keeping with the use of professional technical assistance. Therefore, quality data was a criterion for including these farms in the study. The information collected was for fiscal year 2010-2011. Data collected included farm land area, animal stocks, animals sold, and weight of each animal category (calves, heifers, cows, etc.) and inputs used on rearing activities. On average these cow-calf systems had $602 \mathrm{ha}, 16 \%$ of improved pasture area, $76 \%$ weaning rate, beef cattle stocking rate of 0.61 LU.ha-1, and produced $78 \mathrm{~kg}$ of beef LWG.ha ${ }^{-1}$ (Molina, 2012).

On-farm available information included animal stocking by categories. Animal weights were reported at the beginning and end of the year. It was assumed that the animals were fed exclusively on the farm native grasslands, improved and sown pastures, and annual winter crops for grazing (supplements were consider negligible, because it was less than $1 \%$ dry matter intake). Feed intake quality ( $\%$ digestibility and $\%$ crude protein) was predicted considering land-use on each farm and forage dry matter production, assuming equal forage utilization for all pastures. Diet digestibility and crude protein of each pasture type was obtained from published national research (Mieres, 2004; Table 2). Dry matter production was estimated for each farm from satellite monitoring of pastures provided by the IPA through the LART project (University of Buenos Aires [UBA], nd). This monitoring system of forage productivity based on Normalized Vegetation Index provides detailed information of pasture productivity at paddock level in the farm. The system uses satellite information translated into forage production taking into account different types of pasture, weather conditions and eco-physiological factors (Grigera, Oesterheld, \& Pacín, 2007).

Table 1. Mean, coefficient of variation (CV), minimum (Min), and maximum (Max), for farm variables describing land use, stocking rates, production performance, forage production and quality of 20 livestock cow-calf systems in Uruguay analyzed in this study. All areas listed are measures as proportions (\%) of the total area under cattle grazing

\begin{tabular}{|c|c|c|c|c|c|}
\hline Farm variable & Unit & Mean & $\mathrm{CV}(\%)$ & Min & Max \\
\hline Total area under cattle grazing & $\mathrm{Ha}$ & 451 & 77 & 100 & 1306 \\
\hline Average paddock size & $\%$ & 12 & 69 & 3 & 33 \\
\hline Soil productivity index ${ }^{1}$ & -- & 81 & 27 & 43 & 114 \\
\hline Grasslands (native) area & $\%$ & 79.5 & 34 & 0.0 & 100.0 \\
\hline Pastures (sown) area & $\%$ & 1.2 & 336 & 0.0 & 18.4 \\
\hline Grasslands oversown with legumes area & $\%$ & 14.9 & 136 & 0.0 & 85.5 \\
\hline Fertilized grasslands & $\%$ & 3.1 & 396 & 0.0 & 55.0 \\
\hline Annual winter forage area & $\%$ & 1.2 & 172 & 0.0 & 6.8 \\
\hline Improved pastures area ${ }^{2}$ & $\%$ & 20.5 & 132 & 0.0 & 100.0 \\
\hline Estimated diet digestibility & $\%$ & 56.5 & 2 & 55.4 & 59.9 \\
\hline Estimated diet crude protein & $\%$ & 10.4 & 11 & 9.4 & 13.7 \\
\hline Forage dry matter production & $\operatorname{kgDM} \cdot \mathrm{ha}^{-1} \cdot \mathrm{y}^{-1}$ & 4427 & 19 & 3250 & 6932 \\
\hline Sheep to cattle (ratio in LU) ${ }^{3}$ & -- & 0.5 & 118 & 0.0 & 2.5 \\
\hline Beef cattle stocking rate & LU.ha ${ }^{-1}$ & 0.55 & 32 & 0.19 & 0.94 \\
\hline Sheep stocking rate & LU.ha ${ }^{-1}$ & 0.20 & 75 & $<.01$ & 0.50 \\
\hline Livestock stocking rate & LU.ha ${ }^{-1}$ & 0.77 & 15 & 0.53 & 0.98 \\
\hline Average cow weight & kgLWG & 377 & 4 & 350 & 410 \\
\hline Forage production allowance ${ }^{4}$ & $\%$ kgDM.kgLWG ${ }^{-1}$ & 4.2 & 24 & 2.9 & 7.1 \\
\hline Calf weaning rate ${ }^{5}$ & $\%$ & 76 & 17 & 46 & 95 \\
\hline
\end{tabular}


Calf weaning weight

Calf weaned weight per served cow ${ }^{6}$

Served cows per ha

Stock efficiency ${ }^{7}$

Calf weaned weight per female stock ${ }^{8}$

Calf weaned weight per area

Beef live weight productivity ${ }^{9}$

$$
\text { kgLWG }
$$

kgLWG

cow.ha ${ }^{-1}$

$\%$

kgLWG

kgLWG.ha ${ }^{-1}$

kgLWG.ha-1
157

115

0.35

0.76

88

62

$104.7 \quad 33$

$140 \quad 190$

$69 \quad 155$

$0.14 \quad 0.63$

$0.61 \quad 0.87$

$51 \quad 127$

$35 \quad 98$

$59.6 \quad 168.2$

${ }^{1}$ Soil productivity index is a relative economic index of historic land productivity of beef, lamb, and wool for each soil type in the country. Average national index is 100 (Ministerio de Ganadería, Agricultura y Pesca [MGAP], nd).

${ }^{2}$ Calculated as the sum of native pastures oversown with legumes, seeded pastures, and annual winter crops for grazing.

${ }^{3}$ One livestock unit (LU) equals one cow of $380 \mathrm{~kg}$ LWG (live weight) producing one calf per year.

${ }^{4}$ Amount of forage dry matter production $(\mathrm{kg})$ per $100 \mathrm{~kg}$ of animal live weight per day. Calculated as forage dry matter production $\left[\mathrm{kg} \cdot \mathrm{ha}^{-1} \cdot \mathrm{yr}^{-1}\right] * 1 /\left(365\right.$ [days.yr $\left.\left.{ }^{-1}\right]\right)^{*} 100 /\left(380\left[\mathrm{~kg} . \mathrm{LU}^{-1}\right]^{*}\right.$ Livestock stocking rate [LU.ha $\left.\left.{ }^{-1}\right]\right)$. This variable integrates the forage production and stocking rate, but is not exactly the same as "forage allowance" sensu Sollenberger, et al. (2005): kg of forage DM available per $\mathrm{kg}$ of animal live weight at a moment in time.

${ }^{5}$ Calculated as the number of weaning calves divided by the number of served (i.e., matted) cows.

${ }^{6}$ Calculated as weaning rate* weaning weight $/ 100$.

${ }^{7}$ Calculated as the number of served (i.e, matted) cows divided by the number of females older than 1 year (heifers and cows).

${ }^{8}$ Calculated as weaning weight per matted cow multiplied by stock efficiency.

${ }^{9}$ Calculated as the sum of total animal live weight sold minus bought, plus the difference in stocks (changes in animal categories), minus $\mathrm{kg}$ consumed on farm, in the year.

Table 2. Net energy concentration (NEma), digestibility (Dig), and crude protein (CP), and number of samples analyzed (n) for four typical forages used in livestock systems in Uruguay (from Mieres, 2004). Values are overall means across the country and seasons

\begin{tabular}{|c|c|c|c|c|}
\hline Forages & $\begin{array}{l}\text { NEma } \\
\left(\text { Mcal.kg DM }{ }^{-1}\right)\end{array}$ & $\begin{array}{l}\text { Dig } \\
(\% \mathrm{DM})\end{array}$ & $\begin{array}{l}\mathrm{CP} \\
(\% \mathrm{DM})\end{array}$ & $\mathrm{N}$ \\
\hline Grasslands (native) & 1.33 & 55.4 & 9.4 & 940 \\
\hline Grasslands oversown with legumes & 1.44 & 59.7 & 13.4 & 520 \\
\hline Pastures (sown, mixed grass and legumes) & 1.55 & 63.0 & 18.1 & 300 \\
\hline Annual winter forage (oats and ryegrass) & 1.59 & 64.8 & 16.4 & 450 \\
\hline
\end{tabular}

\subsection{Coefficients and Equations for GHG Emissions}

Coefficients and equations for IPCC tier 2 protocols were used to assess GHG emissions (IPCC, 2006). There were no available data on specific emission factors for Uruguay therefore IPCC default values were used (Table 3). The amounts of nutrients required for the animal stock were calculated following IPCC (2006) guidelines according with Agricultural and Food Research Council [AFRC] (1993) and National Research Council [NRC] (1996). Net energy requirements for cattle in each category were estimated from the energy levels needed for maintenance, activity, growth, pregnancy, and lactation. For maintenance requirements weight was assumed to change linearly between the beginning and the end of the year, except for breeding bulls and cows whose weight was considered constant and equal to the average between beginning and end of the year. Activity coefficients corresponding to each animal feeding situation were IPCC (2006) default values (17\% vs 36\% for animals grazing high vs low forage dry matter available, respectively). Net energy needed for growth was estimated by taking into account the average daily weight gain of the animals with the exception of breeding bulls and cows. For lactation energy requirements a production of $41 . \mathrm{cow}^{-1}$.day ${ }^{-1}$ was assumed during the lactation period 
(Franco, Echenagusia, Nuñez, Pereyra, \& Riani, 2002). The gross energy intake was estimated by using the energy content of the diet (Table 2). In order to cross-check that values were biologically realistic, dry matter intake for mature and growing cattle was calculated based on the body weight of the animals (NRC, 1996) and it was $2-3 \%$ of the body weight (which is realistic).

Table 3. Sources of GHG emissions, equation or emission factor used, and reference

\begin{tabular}{|c|c|c|c|}
\hline Gas & Source & Equation/emission factor & Reference \\
\hline \multirow[t]{2}{*}{ Methane } & $\begin{array}{l}\text { Enteric } \\
\text { Fermentation }\end{array}$ & $\begin{array}{l}\mathrm{CH}_{4 \text { Entr }}=\mathrm{EF}_{\mathrm{e}}^{* \mathrm{~N}} \\
E F_{e}=\left(\mathrm{GE}^{*}\left(\mathrm{Y}_{\mathrm{m}} / 100\right) * \text { Days }\right) / 55.65\end{array}$ & IPCC, 2006 \\
\hline & Pasture Manure & $\begin{array}{l}\mathrm{CH}_{4 \mathrm{Man}=} \mathrm{EF}_{\mathrm{m}} * \mathrm{~N} \\
E F_{m}=\mathrm{VS}^{*} \mathrm{Days}^{*}\left[\mathrm{~B}_{\mathrm{o}} * 0.67 *(\mathrm{MCF} / 100) * \mathrm{MS}\right] \\
\mathrm{VS}=\left[\mathrm{GE}^{*}(1-\mathrm{DE} / 100)+(\mathrm{UE})\right]^{*}[(1-\mathrm{ASH} / 18.45)]\end{array}$ & IPCC, 2006 \\
\hline \multirow{4}{*}{$\begin{array}{l}\text { Nitrous } \\
\text { Oxide } \\
\text { Direct }\end{array}$} & $\begin{array}{l}\text { Soil } \mathrm{N} \text { inputs } \\
\text { (fertilizer) }\end{array}$ & $\mathrm{N}_{2} \mathrm{O}_{\mathrm{D}}=\left[\mathrm{F}_{\mathrm{SN}} * \mathrm{EF}_{1}+\mathrm{F}_{\mathrm{PRP}} * \mathrm{EF}_{3}\right] * 44 / 28$ & IPCC, 2006 \\
\hline & & $E F_{1=} 0.01 \mathrm{~kg} \mathrm{~N} 2 O-N(\mathrm{~kg} \mathrm{~N})-1$ & \\
\hline & & $E F_{3=} 0.02 \mathrm{~kg} \mathrm{~N} 2 O-N / \mathrm{kg} \mathrm{N}$ & \\
\hline & Pasture Manure & $\mathrm{Nex}=\mathrm{N}$ intake. $*$ (1- $\mathrm{N}$ retention.) & \\
\hline \multirow{7}{*}{$\begin{array}{l}\text { Nitrous } \\
\text { Oxide } \\
\text { Indirect }\end{array}$} & Pasture Manure & $\begin{array}{l}\mathrm{N}_{2} \mathrm{O}_{\mathrm{ATD}}=\left[\left(\mathrm{F}_{\mathrm{SN}} * \mathrm{Frac}_{\mathrm{GasF}}\right)+\left(\mathrm{F}_{\mathrm{PRP}} * \mathrm{Frac}_{\mathrm{GasM}}\right)\right] * \mathrm{EF}_{4} \\
*(44 / 28)\end{array}$ & IPCC, 2006 \\
\hline & Volatilization & $\operatorname{Frac}_{G a s F}=0.1$ & \\
\hline & & $\operatorname{Frac}_{\text {GasM }}=0.2$ & \\
\hline & & $E F_{4}=0.01 \mathrm{~kg} \mathrm{~N}_{2} \mathrm{O}-\mathrm{N}$ & \\
\hline & Pasture Manure & $\mathrm{N}_{2} \mathrm{O}_{\mathrm{L}}=\left[\left(\mathrm{F}_{\mathrm{SN}}+\mathrm{F}_{\mathrm{PRP}}\right) * \mathrm{Frac}_{\mathrm{L}} \times \mathrm{EF}_{5}\right] \times 44 / 28$ & IPCC, 2006 \\
\hline & Leaching & $\operatorname{Frac}_{L}=0.3$ & \\
\hline & & $E F_{5}=0.0075 \mathrm{~kg} \mathrm{~N}_{2} \mathrm{O}-\mathrm{N}$ & \\
\hline \multirow{9}{*}{$\begin{array}{l}\text { Carbon } \\
\text { Dioxide }\end{array}$} & & $\mathrm{CO}_{2}=$ Fuel (1) $\mathrm{EFF}_{\mathrm{c}}$ & IPCC, 2006 \\
\hline & $\begin{array}{l}\text { Sowing and input } \\
\text { application }\end{array}$ & $E F_{c}=3 \mathrm{~kg} \mathrm{CO} / \mathrm{kg}$ diesel & MGAP, 2013 \\
\hline & $\mathrm{N} \quad$ fertilizer & & \\
\hline & production and & $3.18 \mathrm{~kg} \mathrm{CO} / \mathrm{kg}$ & MGAP, 2013 \\
\hline & transport & & \\
\hline & $\mathrm{P} \quad$ fertilizer & & \\
\hline & $\begin{array}{l}\text { production and } \\
\text { transport }\end{array}$ & $1.43 \mathrm{~kg} \mathrm{CO} / \mathrm{kg}$ & MGAP, 2013 \\
\hline & $\begin{array}{l}\text { Energy to produce } \\
\text { herbicide }\end{array}$ & $18.25 \mathrm{~kg} \mathrm{CO} / \mathrm{l}$ & MGAP, 2013 \\
\hline & $\begin{array}{l}\text { Energy to produce } \\
\text { seed }\end{array}$ & $0.13-0.38 \mathrm{~kg} \mathrm{CO} / \mathrm{kg}$ & MGAP, 2013 \\
\hline
\end{tabular}

$\mathrm{CH}_{4 \mathrm{Ent}}=$ total methane emissions from Enteric Fermentation; $\mathrm{EF}_{\mathrm{e}}=\mathrm{CH}_{4}$ emission factor for enteric fermentation; $\mathrm{N}=$ number of heads of livestock category; $\mathrm{GE}=$ gross energy; $\mathrm{Y}_{\mathrm{m}}=$ methane conversion factor, per cent of gross energy in feed converted to methane; $\mathrm{DE}=$ Digestibility; $\mathrm{CH}_{4 \mathrm{Man}}=$ emissions from manure management, for a defined population; $\mathrm{EF}_{\mathrm{m}}=\mathrm{CH}_{4}$ emission factor from manure management; $\mathrm{VS}=$ daily volatile solid excreted for livestock category $(=0.04 \mathrm{GE}) ; \mathrm{Bo}=$ maximum methane producing capacity for manure produced by livestock category $(0.1)$; MCF = methane conversion factors for each manure management system $(1.5 \%)$; $\mathrm{MS}=$ fraction of 
livestock category manure handled using manure management system (1); ASH $=$ ash content of manure calculated as a fraction of the dry matter feed intake (0.08); UE = urinary energy expressed as fraction of GE (UE* $\mathrm{GE}) ; \mathrm{N}_{2} \mathrm{O}$ D $=$ annual direct $\mathrm{N}_{2} \mathrm{O}-\mathrm{N}$ emissions produced from managed soils; $\mathrm{F}_{\mathrm{SN}}=$ annual amount of synthetic fertilizer $\mathrm{N}$ applied to soils; $\mathrm{EF}_{1}=$ emission factor for $\mathrm{N}_{2} \mathrm{O}$ emissions from $\mathrm{N}$ inputs; $\mathrm{F}_{\mathrm{PRP}}=$ annual amount of urine and dung $\mathrm{N}$ deposited by grazing animals on pasture, range and paddock; $\mathrm{EF}_{3}=$ emission factor for $\mathrm{N}_{2} \mathrm{O}$ emissions from urine and dung $\mathrm{N}$ deposited on pasture, range and paddock by grazing animals; $\mathrm{N}_{\mathrm{ex}}=$ annual average $\mathrm{N}$ excretion per head of category; $\mathrm{N}_{\text {intake }}=$ the annual $\mathrm{N}$ intake per head of animal of category; $\mathrm{N}_{\text {retention }}=$ fraction of annual $\mathrm{N}$ intake that is retained by animal of category; $\mathrm{N}_{2} \mathrm{O}_{\text {ATD }}=$ annual amount of $\mathrm{N}_{2} \mathrm{O}-\mathrm{N}$ produced from atmospheric deposition of $\mathrm{N}$ volatilised from managed soils; $\mathrm{Frac}_{\mathrm{GasF}}=$ fraction of synthetic fertiliser $\mathrm{N}$ that volatilises as $\mathrm{NH}_{3}$ and $\mathrm{NO}_{\mathrm{x}} ; \mathrm{Frac}_{\mathrm{GasM}}=$ fraction of applied organic $\mathrm{N}$ fertilizer materials and of urine and dung $\mathrm{N}$ deposited by grazing animals that volatilises as $\mathrm{NH}_{3}$ and $\mathrm{NO}_{\mathrm{x}} ; \mathrm{EF}_{4}=$ emission factor for $\mathrm{N}_{2} \mathrm{O}$ emissions from atmospheric deposition of $\mathrm{N}$ on soils and water surfaces; Frac $_{\mathrm{L}}=$ fraction of all $\mathrm{N}$ added to/mineralised in managed soils in regions where leaching/runoff occurs that is lost through leaching and runoff; $\mathrm{EF}_{5}=$ emission factor for $\mathrm{N}_{2} \mathrm{O}$ emissions from $\mathrm{N}$ leaching and runoff; $\mathrm{EF}_{\mathrm{c}}=$ emission factor for $\mathrm{CO}_{2}$ from fuel combustion.

Methane emissions from enteric fermentation were calculated using the methane conversion factor $(\mathrm{Ym})$ which is the percent of gross energy (GE) loss by methane, using the average default IPCC value $(6.5 \%)$, which is similar to the Ym measured in Uruguay for dairy cows (Dini et al., 2012). Methane emissions from manure were estimated considering pasture management system according to IPCC (2006), that is, manure deposited during grazing. Emissions from soils were calculated based on urine and dung deposited on pasture during grazing, and synthetic nitrogen fertilizer applied on pasture. Manure nitrogen was estimated taking into account GE intake from diet, $\mathrm{CP} \%(6.25 \mathrm{x} \mathrm{kg} \mathrm{N})$ and default retention of the animals $\left(0.07 \mathrm{~kg} \mathrm{~N}\right.$ retained.animal ${ }^{-1}$.year $\left.{ }^{-1}\right)$ according to IPCC (2006). Fertilizer inputs were estimated as $2.7,6.8$, and $90.6 \mathrm{~kg} \mathrm{~N} \mathrm{ha}^{-1}$.year ${ }^{-1}$ for grasslands oversown with legumes, sown pastures, and annual winter forage respectively, based on local experts' opinions. Indirect emissions from managed soils include leaching and volatilization of applied nitrogen. Biological nitrogen fixation has been removed as a direct source of $\mathrm{N}_{2} \mathrm{O}$ in the IPCC methodology because of the lack of evidence of significant emissions arising from the fixation process itself (Rochette \& Janzen, 2005).

Emissions from burning fossil fuels were calculated according to the tier 1 methodology (IPCC, 2006) taking into account national emission factor for diesel fuel burning $\left(3.0 \mathrm{~kg} \mathrm{CO}_{2}\right.$-e. $\left.{ }^{-1}\right)$. Machinery operations on farm included: sowing pastures (assuming no tillage, which is the common practice) and applying fertilizer and herbicides (7, 2, and 11 ha $^{-1}$, respectively (Cámara Uruguaya de Servicios Agropecuarios [CUSA, Uruguayan Chamber of Agricultural Services], 2011). Four fertilizer applications were assumed in eight years in the case of grasslands oversown with legumes, one herbicide, and two fertilizer applications in sown pastures, and two herbicide applications to prepare soil and one fertilizer application in annual winter forages (also no tillage, fertilizer use was averaged over the years). Emissions from infrastructure (such as machinery, equipment or buildings) were excluded based on lack of currently available data and because it is assumed that they have no significant impact (Frischknecht \& Jungbluth, 2007). In addition, electricity and personal transportation did not vary significantly between farms and were considered negligible. Equilibrium conditions were assumed in soil organic carbon associated with grass-based beef production, and possible $\mathrm{CO}_{2}$ emissions or removal were ignored according to IPCC guidelines. There was no land use change from deforestation in any of the cow-calf systems.

\subsection{Statistical Analysis}

The correlation matrix was calculated among all variables with two objectives: to identify co-linearity (variables that are highly correlated) before performing the multivariate analyses, and to identify which variables were more linearly associated to carbon footprint. For the variable with highest correlation, various regression analysis were performed to identify the model that best fit the data, using Aikake's Information Criterion (AIC) to select for the best model.

A Principal Components Multivariate Analysis was performed in order to reduce the number of explanatory variables, using variables that were not collinear. Seven variables were included in the analysis: calf weaning rate (\%), stock efficiency (served cows/females older than 1 year, \%), beef live weight productivity $\left(\mathrm{kgLWG} \cdot \mathrm{ha}^{-1}\right)$, forage production allowance $\left(\% \mathrm{kgDM} \cdot \mathrm{kgLWG}^{-1}\right)$, livestock stocking rate $\left(\mathrm{LU}_{\mathrm{h}} \mathrm{ha}^{-1}\right)$, carbon footprint per $\mathrm{kg}$ of beef $\left(\mathrm{kgCO}_{2} \mathrm{e} \cdot \mathrm{kgLWG}^{-1}\right)$, and carbon footprint per ha $\left(\mathrm{kgCO}_{2} \mathrm{e} \cdot \mathrm{ha}{ }^{-1}\right)$. A numerical classification of farms was then performed using Ward algorithm with Euclidean distances cluster analysis 
method with the same seven variables. In order to assist in the interpretation of the results from the cluster analysis cluster means were reported for some other variables. An analysis of variance using clusters as classification variable, followed by contrasts between some of the clusters was performed in order to identify differences in the technological changes between clusters. All analyses were conducted by Infostat software (2012).

\section{Results}

\subsection{GHG Emissions From Cow-Calf Systems}

Carbon footprint (the sum of greenhouse gas emissions throughout the life cycle) per kg of weaned calf LWG, per kg of beef production LWG, and per ha showed high variability between farms (Table 4). The difference between the minimum and maximum carbon footprint per $\mathrm{kg}$ of beef was three fold, while for carbon footprint per ha it was two fold. As expected, methane had the largest contribution 75\% (68-78\% of total), followed by nitrous oxide $24 \%$ (22-30\% of total). As expected, GHG emissions per $\mathrm{kg}$ of weaned calf and per $\mathrm{kg}$ of beef were highly correlated $(\mathrm{r}=0.73, \mathrm{P}=0.00027)$. However, $\mathrm{GHG}$ emissions per ha was not correlated with carbon footprint per $\mathrm{kg}$ of beef $(\mathrm{P}=0.51$, Table 5$)$.

Table 4. Mean, coefficient of variation (CV), minimum (Min), maximum (Max), for GHG emissions per kg of weaned calf, per $\mathrm{kg}$ beef production (LWG) and per hectare from 20 cow-calf systems in Uruguay

\begin{tabular}{lllll}
\hline GHG emissions & Mean & $\mathrm{CV}(\%)$ & Min & Max \\
\hline $\mathrm{kg} \mathrm{CO}_{2}$-e $\cdot \mathrm{kg}_{\text {weaned calf }}{ }^{-1}$ & 34.6 & 23 & 21.8 & 51.0 \\
$\mathrm{~kg} \mathrm{CO}$-e $\cdot \mathrm{kg}_{\text {beef } \mathrm{LWG}^{-1}}$ & 20.8 & 26 & 11.4 & 32.2 \\
$\mathrm{~kg} \mathrm{CO}_{2}$-e $\cdot \mathrm{ha}^{-1}$ & 2030 & 18 & 1490 & 2827 \\
\hline
\end{tabular}

\subsection{Variables Correlated With Carbon Footprint}

Diet variables were highly correlated (digestibility, crude protein, forage DM production, forage allowance, Table 5) and also correlated with the proportions of land type of the total area under cattle grazing ( $\%$ area in grasslands, improved pastures, etc.). Cattle reproductive efficiency variables (weaning rate, weaning weight per matted cow and weaning weight per stock efficiency) were also correlated.

Considered independently, several variables had a significant impact on carbon footprint per kg of beef and per ha (Table 5, last two rows). The linear variation in carbon footprint per $\mathrm{kg}$ beef was best explained by beef productivity $(\mathrm{r}=-0.85$, Table 5$)$. In order to identify the shape of the curves for carbon footprint per $\mathrm{kg}$ of beef and beef LWG productivity, three models were compared: a linear model, a quadratic model, and a linear model with the inverse of the independent variable. The AIC values obtained were: 104.1, 104.7, and 102.3 for the linear, quadratic, and inverse model respectively. Therefore, the best model for carbon footprint per $\mathrm{kg}$ was the inverse model: carbon footprint per $\mathrm{kg}=7.02+1299$ (beef productivity) ${ }^{-1}$ (Adjusted $\mathrm{R}^{2}=0.72, \mathrm{p}<0.0001$, Figure 1). A similar procedure was conducted for carbon footprint per ha, and the best model was the simple linear equation: carbon footprint per ha $=1373+6.28$ beef productivity (Adjusted $\mathrm{R}^{2}=0.32, \mathrm{p}=0.0051$ ). 
Table 5. Pearson correlation coefficient (r, below diagonal) and significance level (P, above diagonal) for the simple linear correlations between technological, productive, and carbon footprint variables for 20 cow-calf systems in Uruguay. Significant correlation values are shown in bold $(\mathrm{P}<0.05)$

\begin{tabular}{|c|c|c|c|c|c|c|c|c|}
\hline & ACG & APS & SPI & GRA & PAS & GOL & AWF & IPA \\
\hline Area under cattle grazing (ACG) & & 0.11 & 0.08 & 0.26 & 0.56 & 0.17 & 0.68 & 0.26 \\
\hline Average paddock size (APS) & -0.37 & & 0.46 & 0.09 & 0.56 & 0.16 & 0.27 & 0.09 \\
\hline Soil productivity index (SPI) & -0.4 & -0.17 & & 0.35 & 0.4 & 0.18 & 0.59 & 0.35 \\
\hline Grasslands (native) area (GRA) & 0.26 & 0.38 & -0.22 & & 0.35 & $<.01$ & 0.02 & $<.01$ \\
\hline Pastures (sown) area (PAS) & -0.14 & -0.14 & 0.2 & -0.22 & & 0.62 & $<.01$ & 0.35 \\
\hline Grassl. overs. legume area (GOL) & -0.32 & -0.33 & 0.31 & -0.82 & -0.12 & & 0.83 & $<.01$ \\
\hline Annual winter forage area (AWF) & -0.1 & -0.26 & 0.13 & -0.53 & 0.78 & 0.05 & & 0.02 \\
\hline Improved pastures area (IPA) & -0.26 & -0.38 & 0.22 & -1 & 0.22 & 0.82 & 0.53 & \\
\hline Estimat. diet digestibility (DIG) & -0.27 & -0.4 & 0.27 & -0.97 & 0.39 & 0.76 & 0.66 & 0.97 \\
\hline Estimat. diet crude protein $(\mathrm{CP})$ & -0.24 & -0.41 & 0.24 & -0.99 & 0.32 & 0.78 & 0.62 & 0.99 \\
\hline Forage dry matter prod. (FDM) & -0.17 & -0.49 & 0.23 & -0.79 & 0.26 & 0.49 & 0.58 & 0.79 \\
\hline Forage prod. allowance (FA\%) & 0.03 & -0.55 & -0.13 & -0.62 & 0.03 & 0.38 & 0.43 & 0.62 \\
\hline Sheep to cattle (ratio in LU, SCR) & -0.22 & 0.73 & -0.31 & 0.26 & -0.23 & -0.23 & -0.25 & -0.26 \\
\hline Beef cattle stocking rate (BSR) & 0.05 & -0.58 & 0.39 & -0.19 & 0.5 & 0.13 & 0.31 & 0.19 \\
\hline Sheep stocking rate (SSR) & -0.18 & 0.82 & -0.19 & 0.21 & -0.34 & -0.15 & -0.28 & -0.21 \\
\hline Livestock stocking rate (LSR) & -0.21 & 0.27 & 0.43 & 0.05 & 0.32 & -0.06 & 0.08 & -0.05 \\
\hline Average cow weight (CoW) & 0.03 & -0.2 & 0.19 & -0.24 & 0.15 & $<.01$ & 0.33 & 0.24 \\
\hline Calf weaning rate (WR) & -0.11 & -0.37 & 0.31 & -0.53 & 0.2 & 0.41 & 0.37 & 0.53 \\
\hline Calf weaning weight $(\mathrm{CaW})$ & -0.35 & -0.1 & 0.27 & -0.45 & 0.53 & 0.3 & 0.42 & 0.45 \\
\hline Stock efficiency (SE) & -0.12 & 0.06 & -0.3 & -0.32 & 0.14 & 0.35 & 0.19 & 0.32 \\
\hline Calf weaned weight per ha (CWh) & -0.53 & 0.2 & 0.42 & -0.25 & 0.17 & 0.3 & 0.03 & 0.25 \\
\hline Beef LWG productivity (BP) & -0.58 & 0.11 & 0.57 & -0.17 & 0.22 & 0.2 & 0.07 & 0.17 \\
\hline Carbon Footprint per kg (CFk) & 0.6 & 0.1 & -0.62 & 0.33 & -0.36 & -0.33 & -0.28 & -0.33 \\
\hline \multirow[t]{2}{*}{ Carbon Footprint per ha (CFh) } & -0.22 & 0.37 & 0.17 & 0.09 & -0.22 & -0.05 & -0.33 & -0.09 \\
\hline & DIG & $\mathrm{CP}$ & FDM & FA\% & SCR & BSR & SSR & LSR \\
\hline Area under cattle grazing (ACG) & 0.26 & 0.3 & 0.48 & 0.92 & 0.36 & 0.82 & 0.44 & 0.37 \\
\hline Average paddock size (APS) & 0.08 & 0.07 & 0.03 & 0.01 & $<.01$ & 0.01 & $<.01$ & 0.24 \\
\hline Soil productivity index (SPI) & 0.25 & 0.32 & 0.33 & 0.58 & 0.18 & 0.09 & 0.41 & 0.06 \\
\hline Grasslands (native) area (GRA) & $<.01$ & $<.01$ & $<.01$ & $<.01$ & 0.26 & 0.41 & 0.38 & 0.83 \\
\hline Pastures (sown) area (PAS) & 0.09 & 0.17 & 0.26 & 0.89 & 0.34 & 0.02 & 0.15 & 0.16 \\
\hline Grassl. overs. legume area (GOL) & $<.01$ & $<.01$ & 0.03 & 0.09 & 0.33 & 0.57 & 0.53 & 0.79 \\
\hline Annual winter forage area (AWF) & $<.01$ & $<.01$ & 0.01 & 0.06 & 0.29 & 0.19 & 0.24 & 0.73 \\
\hline Improved pastures area (IPA) & $<.01$ & $<.01$ & $<.01$ & $<.01$ & 0.26 & 0.41 & 0.38 & 0.83 \\
\hline Estimat. diet digestibility (DIG) & & $<.01$ & $<.01$ & 0.01 & 0.18 & 0.19 & 0.26 & 0.86 \\
\hline Estimat. diet crude protein $(\mathrm{CP})$ & 1 & & $<.01$ & $<.01$ & 0.2 & 0.26 & 0.29 & 0.99 \\
\hline Forage dry matter prod. (FDM) & 0.78 & 0.8 & & $<.01$ & 0.07 & 0.15 & 0.1 & 0.82 \\
\hline Forage prod. allowance (FA\%) & 0.56 & 0.6 & 0.73 & & 0.1 & 0.92 & 0.03 & $<.01$ \\
\hline
\end{tabular}




\begin{tabular}{|c|c|c|c|c|c|c|c|c|}
\hline Sheep to cattle (ratio in LU, SCR) & -0.31 & -0.3 & -0.42 & -0.38 & & $<.01$ & $<.01$ & 0.89 \\
\hline Beef cattle stocking rate (BSR) & 0.3 & 0.26 & 0.34 & 0.02 & -0.8 & & $<.01$ & 0.08 \\
\hline Sheep stocking rate (SSR) & -0.26 & -0.25 & -0.38 & -0.48 & 0.88 & -0.76 & & 0.3 \\
\hline Livestock stocking rate (LSR) & 0.04 & $<.01$ & 0.05 & -0.62 & 0.03 & 0.4 & 0.24 & \\
\hline Average cow weight (CoW) & 0.23 & 0.25 & 0.46 & 0.25 & 0.04 & 0.02 & 0.08 & 0.14 \\
\hline Calf weaning rate (WR) & 0.54 & 0.54 & 0.34 & 0.3 & -0.31 & 0.22 & -0.29 & -0.13 \\
\hline Calf weaning weight $(\mathrm{CaW})$ & 0.5 & 0.47 & 0.45 & 0.11 & -0.25 & 0.41 & -0.19 & 0.36 \\
\hline Stock efficiency (SE) & 0.32 & 0.31 & 0.02 & 0.29 & 0.18 & -0.32 & 0.07 & -0.41 \\
\hline Calf weaned weight per ha (CWh) & 0.26 & 0.25 & 0.33 & -0.13 & -0.01 & 0.21 & 0.06 & 0.53 \\
\hline Beef LWG productivity (BP) & 0.2 & 0.17 & 0.36 & -0.15 & -0.11 & 0.29 & $<.01$ & 0.62 \\
\hline Carbon Footprint per kg (CFk) & -0.4 & -0.36 & -0.39 & -0.05 & 0.37 & -0.44 & 0.31 & -0.35 \\
\hline Carbon Footprint per ha (CFh) & -0.16 & -0.13 & 0.14 & -0.31 & 0.22 & -0.05 & 0.4 & 0.61 \\
\hline & $\mathrm{CoW}$ & WR & $\mathrm{CaW}$ & SE & $\mathrm{CWh}$ & $\mathrm{BP}$ & CFk & $\mathrm{CFh}$ \\
\hline Area under cattle grazing (ACG) & 0.9 & 0.65 & 0.13 & 0.62 & 0.02 & 0.01 & $<.01$ & 0.35 \\
\hline Average paddock size (APS) & 0.41 & 0.1 & 0.68 & 0.81 & 0.4 & 0.65 & 0.68 & 0.11 \\
\hline Soil productivity index (SPI) & 0.43 & 0.18 & 0.24 & 0.19 & 0.06 & 0.01 & $<.01$ & 0.46 \\
\hline Grasslands (native) area (GRA) & 0.31 & 0.02 & 0.04 & 0.16 & 0.28 & 0.48 & 0.16 & 0.71 \\
\hline Pastures (sown) area (PAS) & 0.52 & 0.4 & 0.02 & 0.57 & 0.47 & 0.35 & 0.11 & 0.35 \\
\hline Grassl. overs. legume area (GOL) & 1 & 0.07 & 0.19 & 0.13 & 0.2 & 0.4 & 0.15 & 0.84 \\
\hline Annual winter forage area (AWF) & 0.16 & 0.11 & 0.07 & 0.43 & 0.92 & 0.78 & 0.22 & 0.16 \\
\hline Improved pastures area (IPA) & 0.31 & 0.02 & 0.04 & 0.16 & 0.28 & 0.48 & 0.16 & 0.71 \\
\hline Estimat. diet digestibility (DIG) & 0.32 & 0.01 & 0.03 & 0.17 & 0.26 & 0.4 & 0.08 & 0.5 \\
\hline Estimat. diet crude protein $(\mathrm{CP})$ & 0.29 & 0.01 & 0.04 & 0.19 & 0.3 & 0.47 & 0.12 & 0.57 \\
\hline Forage dry matter prod. (FDM) & 0.04 & 0.14 & 0.05 & 0.92 & 0.16 & 0.12 & 0.09 & 0.56 \\
\hline Forage prod. allowance (FA\%) & 0.28 & 0.19 & 0.63 & 0.22 & 0.57 & 0.52 & 0.84 & 0.18 \\
\hline Sheep to cattle (ratio in LU, SCR) & 0.86 & 0.18 & 0.28 & 0.46 & 0.96 & 0.63 & 0.11 & 0.34 \\
\hline Beef cattle stocking rate (BSR) & 0.93 & 0.35 & 0.08 & 0.18 & 0.38 & 0.22 & 0.05 & 0.83 \\
\hline Sheep stocking rate (SSR) & 0.74 & 0.21 & 0.42 & 0.78 & 0.8 & 0.99 & 0.18 & 0.08 \\
\hline Livestock stocking rate (LSR) & 0.54 & 0.58 & 0.12 & 0.07 & 0.02 & $<.01$ & 0.13 & $<.01$ \\
\hline Average cow weight (CoW) & & 0.42 & 0.67 & 0.45 & 0.73 & 0.71 & 0.71 & 0.26 \\
\hline Calf weaning rate (WR) & 0.19 & & 0.93 & 0.84 & 0.22 & 0.43 & 0.05 & 0.43 \\
\hline Calf weaning weight $(\mathrm{CaW})$ & 0.1 & -0.02 & & 0.28 & 0.11 & 0.11 & 0.06 & 0.55 \\
\hline Stock efficiency (SE) & -0.18 & 0.05 & 0.26 & & 0.99 & 0.25 & 0.77 & 0.07 \\
\hline Calf weaned weight per ha (CWh) & 0.08 & 0.29 & 0.37 & $<.01$ & & $<.01$ & $<.01$ & $<.01$ \\
\hline Beef LWG productivity (BP) & 0.09 & 0.19 & 0.37 & -0.27 & 0.74 & & $<.01$ & 0.01 \\
\hline Carbon Footprint per kg (CFk) & 0.09 & -0.45 & -0.43 & 0.07 & -0.61 & -0.85 & & 0.51 \\
\hline Carbon Footprint per ha (CFh) & 0.26 & -0.19 & 0.14 & -0.42 & 0.64 & 0.6 & -0.16 & \\
\hline
\end{tabular}




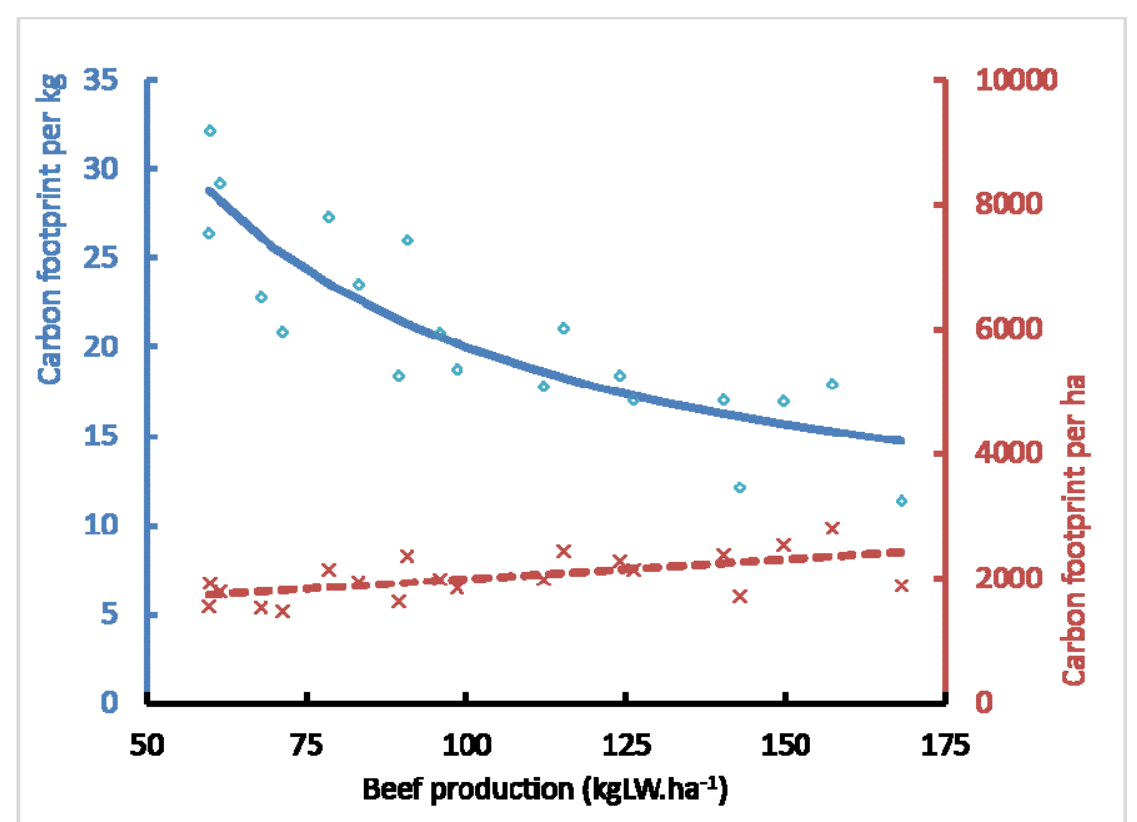

Figure 1. Carbon footprint per kg of LWG beef produced (CFK, left axis, circles) and per hectare (CFH, right axis, crosses) against beef productivity (BP, kgLWG.ha-1) for 20 cow-calf farms in Uruguay. Regression lines are shown: $\mathrm{CFK}=7.02+1299 \mathrm{BP}-1$ (continuous line, $\mathrm{R} 2=0.72, \mathrm{p}<0.0001) . \mathrm{CFH}=1373+6.28 \mathrm{BP}$ (dashed line, $\mathrm{R} 2=0.32, \mathrm{p}=0.0051$ )

\subsection{Multivariate Analyses}

The first two principal components explained $69.2 \%$ of the total variability of the observations (Figure 2). The first principal component explained $42.9 \%$ of the variability between the farms, and was negatively associated with carbon footprint per $\mathrm{kg}$ and stock efficiency, and positively highly correlated with stocking rate, beef productivity, and carbon footprint per ha. The second principal component explained $26.3 \%$ of the variation and was positively highly correlated with weaning rate and forage production allowance, and negatively correlated with carbon footprint per $\mathrm{kg}$ (Table 6).

Table 6. Eigenvalues for the variables in the first two principal components

\begin{tabular}{lll}
\hline Variables & $\mathrm{e} 1$ & $\mathrm{e} 2$ \\
\hline Forage production allowance & -0.30 & 0.42 \\
Calf weaning rate & -0.01 & 0.58 \\
Stock efficiency & -0.32 & 0.18 \\
Beef productivity & 0.49 & 0.32 \\
Carbon footprint per kg & -0.33 & -0.55 \\
Carbon footprint per ha & 0.44 & -0.16 \\
Livestock stocking rate & 0.51 & -0.15 \\
\hline
\end{tabular}




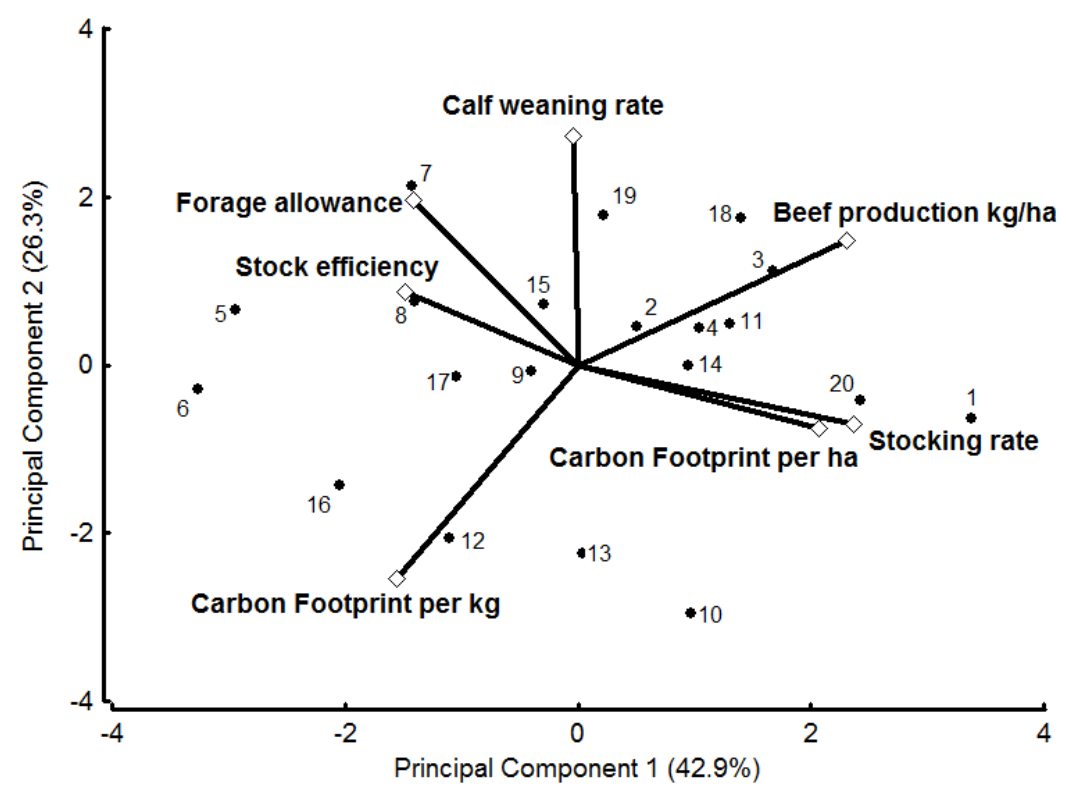

Figure 2. Principal Components Analysis graph showing seven variables (white diamonds and lines): carbon footprint per kg of beef and per ha, calf weaning rate, stock efficiency, forage production allowance, beef production, and livestock stocking rate for 20 cow-calf systems in Uruguay (black dots identified by farm case number)

The cluster analysis performed with the same seven variables as the principal components analysis identified five groups (at the point of half or the total Euclidean distance). The five clusters were labelled in decreasing order of the carbon footprint per $\mathrm{kg}$, from $\mathrm{C} 1$ (highest carbon footprint) to $\mathrm{C} 5$ (lowest). Means for all variables in each cluster are reported in Table 7. According to these variable means, interpretative names were given to each cluster. The "low performance farms" (C 1) had the lowest forage production allowance and high stocking rates, resulting in poor herd reproductive parameters (lowest weaning rate), and therefore lowest beef productivity, and highest carbon footprint per $\mathrm{kg}$ and also high carbon footprint per ha. These farms are also located on the poorest soils and they have the highest sheep stocking rate. The "inefficient grazing farms" (C 2) also have a high carbon footprint per $\mathrm{kg}$, but for a very different reason. These farms have the highest forage production allowance, based on the lowest stocking rate that makes an inefficient use of the pasture. Therefore, they obtain good reproductive performance, but low beef productivity. The "improved grazing farms" (C 3) have an intermediate stocking rate and forage production allowance, resulting in better reproductive performance. However, their stock efficiency is low due to a poor heifer raising (or backgrounding, farmers usually prioritize forage allocation to served cows rather than growing heifers) or accumulation of more heifers than the replacement rate (farmers who sell pregnant heifers). These farms obtain intermediate beef productivity, and carbon footprint per kg. The "most intensified farms" (C 4) obtain the highest beef productivity based on better soils and pasture types, and using the highest stocking rates even though their reproductive performance is average. These farms obtain low carbon footprint per kg, but the highest carbon footprint per ha. Finally, the "carbon smart farms" (C 5) obtain at the same time the lowest carbon footprint per $\mathrm{kg}$ and low carbon footprint per ha, based on high beef productivity and excellent reproductive performance, sustained by high stocking rates on optimal forage production allowance. 
Table 7. Means for relevant farm variables for five farm clusters obtained by numerical classification of 20 cow-calf systems in Uruguay, and significance values $(\mathrm{P})$ for the analysis of variance for each variable between clusters. Variables considered for the clustering algorithm are shown in bold. Means with the same letter are not different between groups (Tukey, $\mathrm{P}<0.05$ ). Clusters interpretative names are: $\mathrm{C} 1$ : Low performance, $\mathrm{C} 2$ : Inefficient grazing, C 3: Improved grazing, C 4: Most intensive, C 5: Carbon smart

\begin{tabular}{|c|c|c|c|c|c|c|c|c|c|c|c|}
\hline Variable (unit) & $\mathrm{C} 1$ & & C 2 & & C 3 & & C 4 & & C 5 & & $\mathrm{P}$ \\
\hline Number of farm cases & 4 & & 3 & & 3 & & 4 & & 6 & & \\
\hline Carbon Footprint $\left(\mathrm{kgCO}_{2} \mathrm{e} \cdot \mathrm{kgLWG}^{-1}\right)$ & 28.7 & $\mathbf{C}$ & 23.3 & bc & 20.8 & $\mathbf{a b}$ & 18.3 & $\mathbf{a b}$ & 16.0 & $\mathbf{a}$ & $<.01$ \\
\hline Carbon Footprint ha $\left(\mathrm{kgCO}_{2} \mathrm{e} \cdot \mathrm{ha}^{-1}\right)$ & 2061 & $\mathbf{A b}$ & 1706 & $\mathbf{a}$ & 1817 & $\mathbf{a}$ & 2551 & b & 1931 & $\mathbf{a}$ & $<.01$ \\
\hline Beef productivity (kg LWG.ha ${ }^{-1}$ ) & 72.8 & $\mathbf{A}$ & 74.5 & $\mathbf{a}$ & 88.9 & $\mathbf{a b}$ & 140.8 & c & 125.0 & bc & $<.01$ \\
\hline Forage prod. allow. (\%kgDM.kgLWG $\left.{ }^{-1}\right)$ & 3.4 & $\mathbf{A}$ & 6.2 & b & 4.2 & $\mathbf{a}$ & 4.0 & $\mathbf{a}$ & 4.0 & $\mathbf{a}$ & $<.01$ \\
\hline Livestock stocking rate (LU.ha $\left.{ }^{-1}\right)$ & 0.81 & B & 0.59 & $\mathbf{a}$ & 0.72 & $\mathbf{a b}$ & 0.86 & b & 0.81 & b & 0.01 \\
\hline Calf weaning rate $(\%)$ & 61 & $\mathbf{A}$ & 78 & $\mathbf{a b}$ & 82 & $\mathbf{b}$ & 72 & $\mathbf{a b}$ & 85 & b & 0.01 \\
\hline Stock efficiency $(\%)$ & 0.77 & $\mathbf{A b}$ & 0.81 & $\mathbf{b}$ & 0.68 & $\mathbf{a}$ & 0.72 & $\mathbf{a b}$ & 0.81 & b & 0.02 \\
\hline Soil productivity index & 61 & & 62 & & 91 & & 90 & & 94 & & 0.04 \\
\hline Area under cattle grazing (ha) & 1319 & & 715 & & 661 & & 486 & & 319 & & 0.18 \\
\hline Sheep stocking rate $\left(\mathrm{LU} \cdot \mathrm{ha}^{-1}\right)$ & 0.36 & & 0.08 & & 0.09 & & 0.21 & & 0.21 & & 0.05 \\
\hline Sheep to cattle (ratio in LU) & 1.2 & & 0.2 & & 0.2 & & 0.5 & & 0.4 & & 0.12 \\
\hline Grasslands (native) (\% area) & 95.3 & & 60.7 & & 93.0 & & 87.9 & & 66.1 & & 0.25 \\
\hline Improved pastures ( $\%$ area) & 4.7 & & 39.3 & & 7.0 & & 12.1 & & 33.9 & & 0.25 \\
\hline Forage dry matter production $\left(\mathrm{kg} \cdot \mathrm{ha}^{-1}\right)$ & 3845 & & 5141 & & 4196 & & 4654 & & 4423 & & 0.32 \\
\hline Beef cattle stocking rate $\left(\right.$ LU.ha $\left.{ }^{-1}\right)$ & 0.43 & & 0.51 & & 0.63 & & 0.59 & & 0.58 & & 0.60 \\
\hline
\end{tabular}

\section{Discussion}

Results from this study are compared with former relevant studies in Table 8. The cow-calf systems analyzed here on average have higher carbon footprint per kg than cow-calf systems based on higher quality seeded pastures and hay, and higher reproductive rates in USA or Canada (Beauchmin et al., 2010, Pelletier et al., 2010). However, the systems studied in this paper with minimum values are similar to those reported from USA and Canada. This suggests that the more efficient grazing systems like the ones in Uruguay have similar carbon footprint to those of the USA and Canada. The differences can be explained through quality of the diet as well as reproductive performance of the herds. These results were consistent with previous research, which has shown that GHG intensity can also be reduced through changes in animal husbandry practices that increase animal outputs (e.g., increasing the number of calves weaned, improving forage quality for breeding stock and improvements on cow fertility; Beauchmin et al., 2011).

The GHG emissions were similar to former values for Uruguay $1895 \mathrm{~kg} \mathrm{CO}_{2}$-e.ha ${ }^{-1}$ and $18.4 \mathrm{~kg} \mathrm{CO}_{2}$-e kgLWG $\mathrm{kgL}^{-1}$ found in a cow-calf system case study (Becoña, Ledgard, \& Wedderburn, 2013) with $90 \%$ calf weaning rate. Compared to the second phase (backgrounding, growing from 150 to $350 \mathrm{~kg}$ ) and third phase (finishing, growing from 350 to $500 \mathrm{~kg}$ or slaughter) of grasslands based beef systems from Uruguay (Modernel, et al., 2013), on average cow-calf systems have higher carbon footprint, but the ranges overlap. Therefore, improving efficiency in cow-calf systems in Uruguay can have a major impact on beef carbon footprint.

Compared to the systems from southern Brazil, the systems analyzed here are similar to the improved pastures ones, and lower than the natural grasslands one (Ruviaro et al., 2014). This suggests that in the region, of the systems based on natural grasslands, the systems from Uruguay are more efficient and produce less GHG emissions, probably due to the better quality of the temperate pastures compared to the more subtropical ones.

The wide range of carbon footprint estimations found in individual farms suggests that assuming an average carbon footprint value for the country based on these 20 systems would be an oversimplification. The most useful carbon footprint comparisons are performed at the farm level, not at the country level.

There is no clear concensus in the literature as to which is the best way to present GHG intensity in cow-calf 
systems. Ogino et al. (2007) reported GHG emissions per calf produced in cow-calf systems and did not consider the finishing of the beef cows. Pelletier et al. (2010) included the $\mathrm{kg}$ of culled cows sent to slaughter in addition to the $\mathrm{kg}$ of weaned calf. Beauchemin et al. (2010) supported this way of accounting, including cull bulls in addition to cull cows and weaned calves. In this study, and in agreement with the last two, as the objective is to account for GHG emissions in the entire system, i.e. cow-calf and finishing phase, is necessary to take into account sub-products from cow-calf systems such as cull cows.

Table 8. Comparison of grasslands and pasture based beef systems carbon footprint ( $\left.\mathrm{kg} \mathrm{CO}_{2} \mathrm{e}-\mathrm{kg} \mathrm{LWG}-1\right)$ from various studies

\begin{tabular}{|c|c|c|c|c|c|c|}
\hline Beef system & Feed base & Min & Mean & Max & Country & Reference \\
\hline \multirow{3}{*}{ cow-calf } & $\begin{array}{l}\text { Native grasslands and improved } \\
\text { pastures }\end{array}$ & 11.4 & 20.8 & 32.2 & Uruguay & This paper \\
\hline & Mixed hay and pasture & & 10.4 & & Canada & $\begin{array}{l}\text { Beauchmin } \\
\text { et al., } 2010\end{array}$ \\
\hline & $\begin{array}{l}40 \% \text { legume pasture, grasss hay, and } \\
\text { wheat }\end{array}$ & & 10.5 & & USA & $\begin{array}{l}\text { Pelletier et } \\
\text { al., } 2010\end{array}$ \\
\hline finishing only & $\begin{array}{l}40 \% \text { legume pasture, brome pasture, } \\
\text { grass and alfalfa hay }\end{array}$ & & 8.7 & & USA & $\begin{array}{l}\text { Pelletier et } \\
\text { al., } 2010\end{array}$ \\
\hline \multirow{11}{*}{$\begin{array}{l}\text { backgrounding- } \\
\text { finishing }\end{array}$} & Natural grasslands & & 16.7 & & & \\
\hline & Natural grasslands-seeded pastures & & 13.0 & & Uruguay & $\begin{array}{l}\text { Modernel } \\
\text { et al., } 2013\end{array}$ \\
\hline & Seeded pastures & & 9.5 & & & \\
\hline & pastures and supplements & & 19.3 & & Australia & $\begin{array}{l}\text { Peters et } \\
\text { al., } 2010\end{array}$ \\
\hline & Natural grass & 39.3 & 42.6 & 46.5 & \multirow{7}{*}{ Brazil } & \multirow{7}{*}{$\begin{array}{l}\text { Ruviaro et } \\
\text { al., } 2014\end{array}$} \\
\hline & Improved natural grass & 18.7 & 20.2 & 22.0 & & \\
\hline & Natural grass/ryegrass & 27.2 & 29.6 & 32.6 & & \\
\hline & Improved natural grass/sorghum & 21.1 & 23.4 & 25.4 & & \\
\hline & Cultivated ryegrass and sorghum & 18.3 & 20.0 & 21.8 & & \\
\hline & $\begin{array}{l}\text { Natural grass suppl. with protein } \\
\text { mineralised salt }\end{array}$ & 30.6 & 33.3 & 36.6 & & \\
\hline & $\begin{array}{l}\text { Natural grass suppl. with protein energy } \\
\text { mineralised salt }\end{array}$ & 21.1 & 23.4 & 26.1 & & \\
\hline
\end{tabular}

Increasing the stock efficiency, the number of calves weaned and their weight could increase GHG emissions through increasing the number of animals in the system; however as our results show, in our case actually resulted in lower GHG emissions per $\mathrm{kg}$ of calf due to increased system efficiency. Beauchemin et al. (2011) found that practices that improved calf survival to weaning reduced GHG emissions by $4 \%\left(\mathrm{~kg} \mathrm{CO}_{2}\right.$-e.kg beef $\left.{ }^{1}\right)$.

Diet digestibility has a direct effect on reducing $\mathrm{CH}_{4}$ emission intensity and $\mathrm{CH}_{4}$ emissions per kg of dry matter intake (e.g. Pinares-Patiño, Waghorn, Hegarty, \& Hoskin, 2009). The mitigation effect was to reduce GHG emissions by $5 \%$ when DM digestibility increased from 55 to $60 \%$ with a crude protein from $120-140 \mathrm{~g} / \mathrm{kg} \mathrm{DM}$ (Beauchmin, et al., 2011). Eckard, Grainger, \& de Klein (2010) reported that when intake of crude protein exceeded requirements, the higher ruminal ammonia concentrations increased urea excreted in the urine, increasing $\mathrm{N}_{2} \mathrm{O}$ emissions. However, for native grasslands with average crude protein content of 94 g.kgDM ${ }^{-1}$ which represents a nutrient restriction to animal performance, increasing crude protein enhanced animal performance, due to balancing the protein-to-energy ratio in the diets and therefore reducing $\mathrm{N}_{2} \mathrm{O}$ intensity. This effect was clear in farms where the area of improved pastures was increased. These results are consistent with Beukes, Gregorini, Romera, Levy, \& Waghorn (2010) who found that increases in production efficiency may result in more production for the same dry matter intake, but not necessarily in net reduction of GHG emissions. 
The analysis of clusters presented in Figure 3 provides an interpretation of possible pathways of technological change to reduce carbon footprints of cow-calf systems. In order to move from C 1 (Low performance farms) to C 3 (improved grazing), livestock managers can reduce stocking rate, and therefore increase forage allowance, without increasing the area of improved pastures. This can result in a reduction of $28 \%$ of carbon footprint per $\mathrm{kg}$, and $11 \%$ per ha, by increasing $36 \%$ calf weaning rate, with an increase in $22 \%$ in beef productivity. Similarly, to move from C 2 (inefficient grazing) to $\mathrm{C} 3$ (improved grazing), livestock managers can increase the stocking rate and reduce forage allowance, which can result in a reduction of $11 \%$ in carbon footprint per $\mathrm{kg}$, and an increase of $19 \%$ in beef productivity. In order to further reduce carbon footprint and move from C 3 (improved grazing) to C 5 (carbon smart), larger investments in improved pastures are required, which can allow for an increase in stocking rates, stock efficiency, and weaning rate. This can increase beef productivity by $41 \%$ and reduce carbon footprint per $\mathrm{kg}$ by $23 \%$. A further move from C 5 (carbon smart) to C 4 (most intensified) requires an increase in stocking rates, that allows for an increase in beef productivity of $12 \%$, but if forage allowance is reduced, reproductive performance is affected, and both carbon footprint per $\mathrm{kg}$ and per ha can increase $14 \%$.

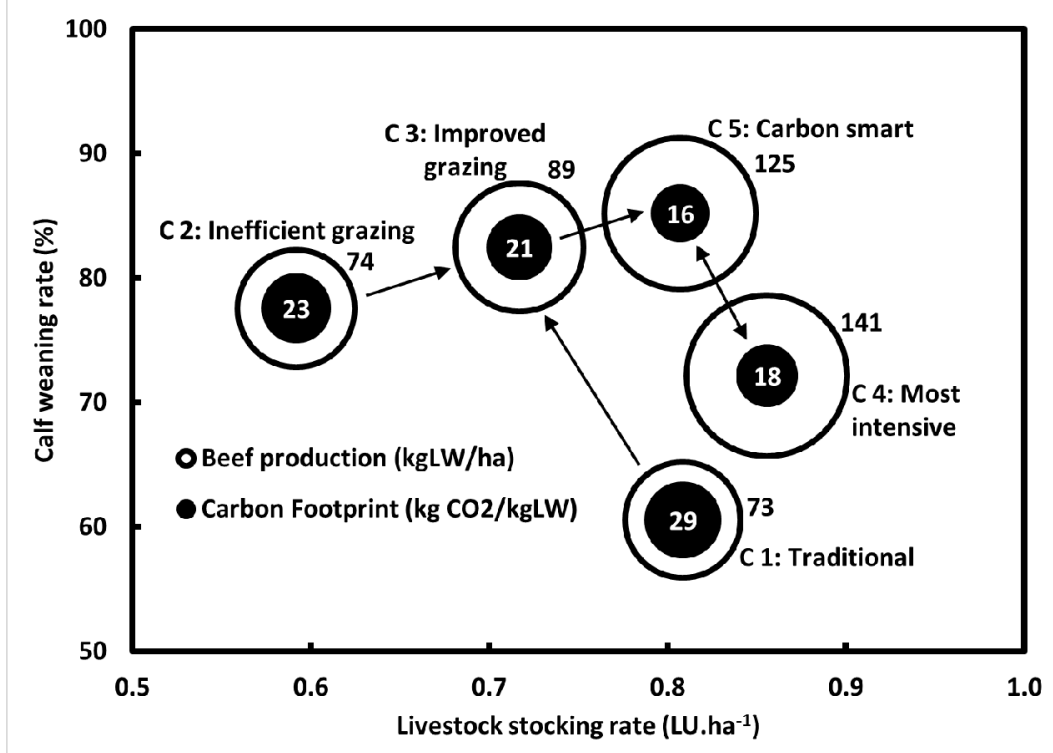

Figure 3. Representation of five farm clusters using four relevant variable means: livestock stocking rate (LU.ha-1, $\mathrm{X}$ axis), calf weaning rate (\%, Y axis), carbon footprint per $\mathrm{kg}\left(\mathrm{kgCO}_{2} \mathrm{e} . \mathrm{kgLWG}-1\right.$, solid circles, values in center of circle), beef productivity (kgLWG.ha-1, outer circles, values in top right of circle). Clusters are labelled with original numbers ( $\mathrm{C} 1$ to $\mathrm{C} 5)$ and interpretative names. Arrows represent potential pathways of technological change to improve performance

It should be highlighted that although when carbon footprint per $\mathrm{kg}$ of live weight is reduced usually carbon footprint per ha is increased, it is empirically possible to reduce at the same time both parameters, like when moving from $\mathrm{C} 1$ to $\mathrm{C} 3$ or from $\mathrm{C} 4$ to $\mathrm{C} 5$. It is further relevant to note that in these two examples, the key factor is reducing stocking rate (or increasing forage allowance). Therefore, in grazing beef cow-calf systems, management schemes that use forage efficiently by optimizing forage allowance, both carbon footprint per $\mathrm{kg}$ of beef and per ha can be minimized. This is consistent with experimental results from Carriquiry et al. (2012), which show that optimizing forage allowance in cow-calf grazing systems reduces energy lost to maintenance and maximizes beef weight gain.

These potential technological trajectories suggest that is possible to reduce carbon footprint without major investments, based mainly on the proper forage management and stocking rates. Moreover, this shows that it is possible to considerably reduce carbon footprint using available technologies in Uruguay.

Sustainability in the food supply chain is a significant challenge in an increasingly competitive food sector. In order to be better prepared to confront this challenge, further work is needed in countries with large livestock 
populations to identify systems that can sustainably produce beef considering a holistic perspective, including other environmental attributes in addition to GHG emissions. In this paper the focus was on carbon footprint, but other environmental impacts of livestock production should be assessed (soil erosion, fossil energy consumption, pesticide risk, $\mathrm{N}$ and $\mathrm{P}$ nutrient balances) in order to make recommendations to farmers and policy makers, because trade off among these variables exist (Modernel et al., 2013). In fact, grasslands in Uruguay and worldwide are challenged by the expansion of agriculture, and more intensified livestock systems based on silage and grains are growing. Although these more intensified systems may have reduced carbon footprint per $\mathrm{kg}$ of beef, they have other environmental impacts like greater soil erosion, nutrient leaching, and pesticide use (Modernel et al., 2013). Land use decisions should be informed by all these environmental variables, and not only carbon footprint.

\section{Conclusion}

Our results suggest that grazing cow-calf systems have a wide range of carbon footprint values. If low carbon footprint is required in the future as a condition to access high-value beef markets, this study suggests that grazing cow-calf systems can significantly improve their competitiveness based on better grazing management and pasture quality. In summary, it is possible to reduce cow-calf GHG emissions using existing management practices in many countries like Uruguay. As Krausmann et al. (2013) suggest, future improvements in pasture productivity and grazing management are needed worldwide, in order to mitigate climate change, and improve performance and efficiency of livestock systems.

\section{Acknowledgements}

We are grateful for the financial support of Centro Interdisciplinario de Respuesta al Cambio y Variabilidad Climática, Espacio Interdisciplinario, Universidad de la República (Uruguay). The authors gratefully acknowledge farmers who provided data and the Instituto Plan Agropecuario to enable access to the information. We are also grateful for the comments from Pablo Speranza, Walther Beathgen, and other anonymous reviewers who improved significantly the quality of the paper.

\section{References}

Agricultural and Food Research Council [AFRC]. (1993). Energy and Protein Requirements of Ruminants (pp. 24-159). CAB International, Wallingford, U.K.

Beauchemin, K. A., Janzen, H. H., Little, S. M., McAllister, T. A., \& McGinn, S. M. (2010). Life cycle assessment of greenhouse gas emissions from beef production in western Canada: A case study. Agricultural Systems, 103, 371-379. http://dx.doi.org/10.1016/j.agsy.2010.03.008

Beauchemin, K. A., Janzen, H. H., Little, S. M., McAllister, T. A., \& McGinn, S. M. (2011). Mitigation of greenhouse gas emissions from beef production in western Canada - Evaluation using farm-based life cycle assessment. Animal Feed Science \& Technology, 166-167, 663-667. http://dx.doi.org/10.1016/j.anifeedsci.2011.04.047

Becoña, G., Ledgard, S., \& Wedderburn, E. (2013). A comparison of greenhouse gas emissions from Uruguayan and New Zealand beef systems. Agrociencia Uruguay, 17, 120-130.

Beukes, P. C., Gregorini, P., Romera, A. J., Levy, G., \& Waghorn, G. C. (2010). Improving production efficiency as a strategy to mitigate greenhouse gas emissions on pastoral dairy farms in New Zealand. Agriculture Ecosystems \& Environment, 136(3/4), 358-365. http://dx.doi.org/10.1016/j.agee.2009.08.008

Bransby, D. I., \& Maclaurin, A. R. (2000). Designing Animal Production Studies. In Mannetje \& Jones (Eds). Field and Laboratory methods for grassland and animal production research. CAB Publishing, New York, NY.

Cámara Uruguaya de Servicios Agropecuarios [CUSA]. (2011). Retrieved from $\mathrm{http}: / /$ www.cusa.org.uy/precios_servicios_agricolas.html

Carriquiry, M., Espasandin, A. C., Astessiano, A. L., Casal, A., Claramunt, M., Do Carmo, M., ... Soca, P. (2012). La cría vacuna sobre campo nativo: Un enfoque de investigación jerárquico para mejorar su productividad y sostenibilidad. Veterinaria (Montevideo) 48(Supl. I), 41-48.

Casey, J. W., \& Holden, N. M. (2006). Quantification of GHG emissions from sucker-beef production in Ireland. Agricultural Systems, 90, 79-98. http://dx.doi.org/10.1016/j.agsy.2005.11.008

De Vries, M., \& de Boer, I. J. M. (2010). Comparing environmental impacts for livestock products: A review of life cycle assessments. Livestock Science, 128, 1-11. http://dx.doi.org/10.1016/j.livsci.2009.11.007 
Dini, Y., Gere, J., Briano, C., Manetti, M., Juliarena, P., Picasso, V., Gratton, R., \& Astigarraga, L. (2012). Methane emission and milk production of dairy cows grazing pastures rich in legumes or rich in grasses in Uruguay. Animals, 2, 288-300. http://dx.doi.org /10.3390/ani2020288

Eckard, R. J., Grainger, C., \& de Klein, C. A. M. (2010). Options for the abatement of methane and nitrous oxide from ruminant production: A review. Livestock Science, 130, 47-56. http://dx.doi.org/10.1016/j.livsci.2010.02.010

Edwards-Jones, G., Plassmann, K., \& Harris, I. M. (2009). Carbon footprinting of lamb and beef production systems: insights from an empirical analysis of farms in Wales, UK. J. Agric. Sci., 147, 707-719. http://dx.doi.org/10.1017/S0021859609990165

Franco, J., Echenagusia, M., Nuñez, A., Pereyra, A., \& Riani, V. (2002). Destete temporario en vacas Hereford bajo pastoreo de campo natural. I. Comportamiento Reproductivo. II. Producción de leche y peso de los terneros al destete. 30 Jornadas Uruguayas de Buiatría. Comunicaciones cortas. Uruguay. pp. 203-206.

Frischknecht, R., \& Jungbluth, N. (2007). Ecoinvent: overview and methodology. Swiss Centre for Life Cycle Inventories, Dübendorf.

Gerber, P. J., Steinfeld, H., Henderson, B., Mottet, A., Opio, C., Dijkman, J., ... Tempio, G. (2013). Tackling climate change through livestock - A global assessment of emissions and mitigation opportunities. Food and Agriculture Organization of the United Nations (FAO), Rome. http://www.fao.org/docrep/018/i3437e/i3437e00.htm

Grigera, G., Oesterheld, M., \& Pacín, F. (2007). Monitoring forage production for farmers' decision making. Agricultural Systems, 94, 637-648. http://dx.doi.org/10.1016/j.agsy.2007.01.001

Infostat. (2012). Infostat. Universidad Nacional de Córdoba, Argentina. Retrieved from www.infostat.com.ar

Intergovernmental Panel on Climate Change [IPCC]. (2006). IPCC Guidelines for National Greenhouse Gas Inventories: Workbook. Volume 4: Agriculture, Forestry and Other Land Use. Prepared by the National Greenhouse Gas Inventories Programme. In H. S. Eggleston, L. Buendia, K. Miwa, T. Ngara \& K. Tanabe (Eds). Kanagawa, Japan: IGES. 2006. Retrieved from http://www.ipcc-nggip.iges.or.jp/public/2006gl/index.htm

Intergovernmental Panel on Climate Change [IPCC]. (2013). Climate Change 2013: The Physical Science Basis. Contribution of Working Group I to the Fifth Assessment Report of the Intergovernmental Panel on Climate Change [In T. F. Stocker, D. Qin, G. K. Plattner, M. Tignor, S. K. Allen, J. Boschung, ... P. M. Midgley (Eds.)]. Cambridge University Press, Cambridge, United Kingdom and New York, NY, USA, p. 1535. Retrieved from https://www.ipcc.ch/report/ar5/wg1/

Krausmann, F., Erb, K. H., Gingrich, S., Haberl, H., Bondeau, A., Gaube, V., ... Searchinger, T. D. (2013). Global human appropriation of net primary production doubled in the 20th century. PNAS, 110(25), 10324-10329. http://dx.doi.org/10.1073/pnas.1211349110

Lizarralde, C., Picasso, V., Rotz, A., Cadenazzi, M., \& Astigarraga, L. (2014). Practices to Reduce Milk Carbon Footprint on Grazing Dairy Farms in Southern Uruguay: Case Studies. Sustainable Agriculture Research, 3, (2), 1-15. http://dx.doi.org/10.5539/sar.v3n2p1

Ministerio de Ganadería, Agricultura y Pesca [MGAP]. (2012). Dirección Estadísticas Agropecuarias. Anuario Estadístico Agropecuario 2011. Retrieved from http://www.mgap.gub.uy/portal/hgxpp001.aspx?7,5,583,O,S,0, (in Spanish)

MGAP. Prender-Coneat. Retrieved from http://www.prenader.gub.uy/coneat/

MGAP. (2013). Proyecto de Huella de Carbono de la Carne Vacuna. Montevideo, Uruguay (in press).

Mieres, J. M. (2004). Guía para alimentación de rumiantes. INIA. Serie técnica $\mathrm{N}^{\circ} 142$. pp. 17-68.

Modernel, P., Astigarraga, L., \& Picasso, V. (2013). Global versus local environmental impacts of grazing and confined beef production systems. Environmental Reserch Letters, 8, 035052.

Molina, C. (2012). Resultados del monitoreo de empresas ganaderas ejercicio 2010-11. Instituto Plan Agropecuario. Uruguay. $\quad$ Retrieved from http://www.planagropecuario.org.uy/MonitoreoDeEmpresasGanaderas.

National Research Council [NRC]. (1996). Nutrients Requirements of Beef Cattle. National Academy Press, Washington, D.C. Retrieved from http://www.nap.edu/openbook.php?record_id=9791\&page=3 
Ogino, A., Orito, H., Shimada, K., \& Hirooka, H. (2007). Evaluating environmental impacts of the Japanese beef cow-calf system by the life cycle assessment method. J. Anim. Sci., 78, 424-432. http://dx.doi.org/10.1111/j.1740-0929.2007.00457.x

Pelletier, N., Pirog, R., \& Rasmussen, R. (2010). Comparative life cycle environmental impacts of three beef production strategies in the Upper Midwestern United States. Agricultural Systems, 103, 380-389. http://dx.doi.org/10.1016/j.agsy.2010.03.009

Peters, G. M., Rowley, H., Wiedemann, S., Tucker, R., Short, M., \& Schulz, M. (2010). Red Meat Production in Australia: Life Cycle Assessment and Comparison with Overseas Studies. Environ. Sci. Technol., 44, 1327-1332. http://dx.doi.org/10.1021/es901131e

Pinares-Patiño, C. S., Waghorn, G. C., Hegarty, R. S., \& Hoskin, S. O. (2009). Effects of intensification of pastoral farming on greenhouse gas emissions in New Zealand. NZ Vet. Journal, 57, $252-261$. http://dx.doi.org/10.1080/00480169.2009.58618

Reisinger, A., \& Ledgard, S. (2013). Impact of greenhouse gas metrics on the quantification of agricultural emissions and farm-scale mitigation strategies: a New Zealand case study. Environ. Res. Lett., 8, 025019 (8pp)

Rochette, P., \& Janzen, H. H. (2005). Towards a revised coefficient for estimating $\mathrm{N}_{2} \mathrm{O}$ emissions from legumes. Nutrients. Cycl. Agroec, 73, 171-179. http://dx.doi.org/10.1007/s10705-005-0357-9

Royo Pallares, O, E. Berretta y G. Maraschin, 2005. The South American Campos ecosystem. In J.M. Suttie, S.G. Reynolds and C. Batello (Eds.) Grasslands of the world. FAO http://www.fao.org/docrep/008/y8344e/y8344e00.htm

Ruviaro, C. F., de Léis C. M., Lampert V. D. N., Barcellos, J. O. J., \& Dewes, H. (2014). Carbon footprint in different beef production systems on a southern Brazilian farm: a case study. Journal of Cleaner Production. http://dx.doi.org/10.1016/j.jclepro.2014.01.037

Sollenberger, L., Moore, J., Allen, V., \& Pedreira, C. (2005). Reporting Forage Allowance in Grazing Experiments. Crop Science, 45(3), 896-900. http://dx.doi.org/10.2135/cropsci2004.0216

Stewart, A. A., Little, S. M., \& Ominski, K. H., Wittenberg, K. M., \& Janzen, H. H. (2009). Evaluating greenhouse gas mitigation practices in livestock systems: an illustration of a whole-farm approach. J. Agric. Sci., 147, 367-382. http://dx.doi.org/10.1017/S0021859609008764

Stuedemann, J. A., \& Franzluebbers, A. J. (2007). Cattle performance and production when grazing Bermudagrass at two forage mass levels in the southern Piedmont J. Anim Sci., 85, 1340-1350. http://dx.doi.org/10.2527/jas.2005-723

University of Buenos Aires [UBA]. Universidad de Buenos Aires. Laboratorio de Análisis Regional y Teledetección LART. Retrieved from http://www.agro.uba.ar/laboratorios/lart

Veysset, P., Lherm, M., \& Bébin, D., (2010). Energy consumption, greenhouse gas emissions and economic performance assessments in French Charolais suckler cattle farms: Model-based analysis and forecasts. Agricultural Systems, 103, 41-50. http://dx.doi.org/10.1016/j.agsy.2009.08.005

\section{Copyrights}

Copyright for this article is retained by the author(s), with first publication rights granted to the journal.

This is an open-access article distributed under the terms and conditions of the Creative Commons Attribution license (http://creativecommons.org/licenses/by/3.0/). 